\title{
Pengaruh Antara Rasio Kecukupan Modal (CAR), Loan To Deposit Ratio (LDR), dan Rasio Biaya Operasional Pendapatan Operasional (BOPO) terhadap Kinerja Profitabilitas Industri Perbankan
}

\author{
Budi Zulfachri \\ Sekolah Tinggi Ilmu Ekonomi Pembangunan Tanjungpinang \\ e-mail: otobar_38@yahoo.com
}

\begin{abstract}
The influence between Capital Adequancy Radio (CAR), Loan to Deposit Ratio (LDR), Operating Cost To Operating Income Ratio on Profitability Performance of Banking Industry. Contribution of banking is very important to encourage economic development especially to increase industry. The important of contribution of bank to economic growth make many parties more concern about profitability performance of banking. Because of that objectives of the research are to know how the influence some of financial ratio which is represented by Capital Adequancy Ratio (CAR), Loan to Deposit Ratio (LDR), Operating Cost To Oprating Income Ratio on Profitability Performance that proxy by WA. The banking population in this research using all of general banking in Indonesia in 2008 amont 123 banking. This research using purposive sampling method to choose "My sample and based on the criteria, has known that 65 banks in Indonesia have a good financial ratio. The research used multiple regression analysis that have been access in normality test and assumption classic test. Based on the results of data hypothesis shoes that LDR has significantly and positively relation on ROA but BOPO has significantly and negatively relation on ROA. Whereas $C A R$ has no significantly on ROA. The contribution of CAR, LDR, and, BOPO influenceses are 69,6\% and the remained is influenced by the other factors which is no described.
\end{abstract}

Keyword: Profitability, CAR, $L D R$, and BOPO.

\section{PENDAHULUAN}

Menurut undang-undang No.7 tahun 1992 yang telah diubah dengan UU No. 10 tahun 1998, perbankan di Indonesia terdiri atas bank umum yang dalam usahanya dapat beroperasi secara konvensional dan atau syariah serta perkreditan rakyat (BPR) yang kegiatan hanya terbatas pada usaha atau syariah. Menurut Kesowo dan Kuncoro (dalam Yuliani, 2007) semakin efisien kinerja operasional suatu bank maka keuntungan yang diperoleh akan semakin besar. Efisien bisa diartikan sebagai perbandingan antar masukan dan keluaran. Dengan pengeluaran biaya tertentu diharapkan memperoleh hasl yang optimal atau dengan hasil tertentu diharapkan mengeluarkan biaya mungkin (Merkusiwati, 2007). Kegiatan menyalurkan dana yang dimilikinya bank dihadapkan pada beberapa resiko (Judisseno, 2002) seperti resiko kurang lancarnya pengambilan pinjaman, bunga pinjaman, dan resiko tidak kembalinya pinjaman (credit risk), resiko akibat perilaku tidak jujur yang dilakukan oleh pihak-pihak terkait dengan perbankan yang dapat mengakibatkan kerugian dan bahkan kehancuran bank (fraud risk), ataupun resiko bank terhadap pemenuhan likuiditas (liquility risk) seperti penyediaan dana minimal (reserve requirement) disamping itu, bank yang dalam kegiatan operasionalnya berbasis pada tingkat suku bunga harus menghadapi resiko negative spread yaitu resiko dimana tingkat suku bunga simpanan lebih besar dari pada tingkat suku bunga 
pinjaman yang akhirnya dapat mengakibatkan bank sulit memperoleh keuntungan.

Berdasarkan data Laporan

Pengawasan Perbankan 2008, LDR Industri perbankan per Desember 2008 berada di sekitar rata-rata sebesar $77,2 \%$ dengan pertumbuhan kredit bank umum sebesar Rp 308,0 triliun $(29,5 \%)$. Nilai ini rata-rata masih berada dibawah normal yaitu pada kisaran 85\%-110\%. Peningkatan nilai LDR diharapkan dapat meningkatkan fungsi intermediasi perbankan serta meningkatkan return yang diperoleh bank atas penyaluran kredit pinjaman yang diberikan. Bagi pihak manajemen bank, pengendalian biaya sangat penting untuk diperhatikan dikarenakan dengan mengendalikan biaya operasional sebuah bank dapat memberikan suku bunga pinjaman yang lebih rendah dan terhindar dari kondisi yang dapat menimbulkan masalah. Namun demikian, berdasarkan data Bank Indonesia per Desember 2008 BOPO (Biaya Operasional terhadap Pendapatan Operasional) bank-bank umum di Indonesia masih relative tinggi yaitu sekitar $84,1 \%$. Angka ini lebih tinggi dari pada tahun 2007 $(78,8 \%)$ dan mengindikasikan belum efisiennya pengendalian yang dilakukan oleh perbankan Indonesia. Setiap bank setidaknya akan berupaya untuk meningkatkan efisien operasional diantaranya dengan melakukan pemaksimalan pendapatan, mengendalikan biaya operasional maupun menjaga rasio kecukupan modal. Untuk bank Indonesia menetapkan rasio kecukupan modal (CAR) minimal yang dipenuhi oleh sebuah bank yaitu sebesar $8 \%$. Apabila CAR sebuah bank dari $8 \%$ maka bank tersebut harus melakukan penambahan modal atau usahanya.

\section{METODE PENELITIAN \\ Operasional Variabel Penelitian}

Menurut Sugiyono (2007), variabel terkait merupakan variabel yang pengaruhi atau yang menjadi akibat karena adanya variabel bebas. Variabel terkait dalam penelitian ini adalah kinerja profitabilitas yang di proxy dengan rasio Return on Assets (ROA). Sedangkan variabel bebas adalah variabel yang mempengaruhi atau yang menjadi sebab pengaruhnya atau timbulnya variabel dependen. Untuk penelitian ini yang termaksud kedalam variabel bebas adalah rasio kecukupan modal (CAR), Loans To Deposit Ratio (LDR) DAN RASIO Biaya Operasional terhadap Pendapatan Operasional (BOPO).

1. Return on Total Assets (ROA)

a. Definisi Konseptual

ROA merupakan rasio yang digunakan untuk mengukur kemampuan bank memperoleh laba dari asset yang dimiliki bank tersebut.

b. Definisi Operasional

$$
\text { ROA }=\frac{\text { Pajak }}{\text { Total Aset }} x 100
$$

2. Rasio Ketikupan Modal (Capital Adequacy Ratio-CAR)

a. Definisi Konseptual

Merupakan ukuran kemampuan bank untuk menutupi seluruh aktiva yang beresiko dengan menggunakan modal sendiri ataupun dana dari pihak lain. Rasio ini dapat dirumuskan sebagai berikut:

b. Definisi Operasional

$$
C A R=\frac{\text { Modal Bank }}{\text { Aktiva Tertimbang }}
$$

3. Loan to Deposit Ratio (LDR)

a. Definisi Konseptual

Rasio ini dapat memperlihatkan besarnya penyaluran kredit suatu bank atas dana pihak ketiga dan modal sendiri yang digunakan serta menunjukan likuiditas suatu bank. Rasio ini dapat dirumuskan dengan :

b. Definisi Operasional

$$
L D R=\frac{\text { Loans }}{\text { Total Deposito }} \times 100 \%
$$

4. Biaya Operasional terhadap Pendapatan Operasional (BOPO)

a. Definisi Konseptual

Rasio BOPO merupakan rasio yang menunjukan kemampuan bank untuk mengendalian biaya operasional yang dihasilkan. Untuk menghitung rasio BOPO dapat menggunakan rumus :

b. Definisi Operasional 


$$
\text { BOPO }=\frac{\text { Biaya Operasional }}{\text { Pendapatan Operasional }} \times 100 \%
$$

\section{Metode Pengumpulan Data}

Data yang digunakan dalam penilitian ini adalah data sekunder yang diperoleh dari berbagai sumber terdiri dari :

1. Data Laporan Keuangan Bank Umum per 31 Desember 2014 yang dipublikasikan dalam Direktori Perbankan Indonesia 2014 yang di peroleh dari perpustakaan Riset Bank Indonesia.

2. Buku-buku, artikel, jurnal, dan penelitian terdahulu yang diperoleh dengan melakukan studi pustaka dari pencarian informasi melalui website yang relavan dengan penelitian ini untuk mengumpulkan data tersebut.

Menurut Sugiyono (2007), populasi merupakan wilayah generalisasi yang terdiri atas objek/subjek yang mempunyai kualitas dan karakteristik tertentu yang di tetapkan peneliti untuk dipelajari kemudian ditarik kesimpulannya. Populasi dalam penelitian ini adalah seluruh bank yang ada di Indonesia baik bank umum maupun bank perkreditan rakyat (BPR).

Sampel merupakan bagian dari populasi. Adapun kriteria yang ditetapkan dalam pengambilan sampel antara lain; (1) Bank yang menerbitkan Laporan Keuangan per 31 Desember 2014 yang dipublikasikan oleh Bank Indonesia dan menyediakan rasio keuangan yang diperlukan dalan penelitian ini; (2) Bank yang diambil sebagai sampel adalah bank yang memiliki rasio keuangan yang telah dianggap sehat berdasarkan ketentuan Bank Indonesia yaitu bank yang memiliki LDR <110\%, BOPO <94\%, CAR $>8 \%$ dan ROA $>1,25 \%$. berdasarkan kriteria yang telah diterapkan, diperoleh 65 bank umum yang dijadikan sampel.

Untuk mengetahui sejauh mana perubahan variabel dependen atas perubahan variabel independen dapat digunakan analisis regresi linier. Terdapat dua jenis regresi linear yaitu analisis regresi linier sederhana dan analisis regresi linier berganda. Dalam penelitian ini terdapat tiga variabel bebas, untuk itu metode analisa yang digunakan adalah analisis regresi linear berganda. Bentuk persamaan regresi berganda yang dapat digunakan untuk meramalkan perubahan kinerja profitabilitas atas perubahan rasio kecukupan modal, loan to deposit ratio, dan rasio biaya operasional pendapatan operasional terhadap adalah :

$Y=a+b_{1} X_{1}+b_{2} X_{2}+b_{3} X_{3}+\varepsilon$

dimana: a adalah intersep atau konstanta; $b_{1}$, $b_{2}$ dan $b_{3}$ adalah nilai koefisien regresi dari masing-masing variabel bebas; $\mathrm{X}_{1}$ adalah Rasio Kecukupan Modal (Capital Adequacy Ratio-CAR); $\mathrm{X}_{2}$ adalah Loan to Deposit Ratio (LDR); $\mathrm{X}_{3}$ adalah Biaya Operasional terhadap Pendapatan Operasional (BOPO); Y adalah Kinerja Profitabilitas (ROA); dan e adalah error term

\section{HASIL ANALISIS}

Berdasarkan kriteria yang telah diterapkan, terpilih sampel sebanyak 65 bank umum yang dapat di klasifikasikan menjadi 6 (enam) jenis status bank seperti terlihat dalam Tabel 1.

Berdasarkan kriteria pemilihan sampel dapat diketahui bahwa tidak ada bank Indonesia yang memiliki rasio kecukupan modal dibawah ketentuan Bank Indonesia $(<8 \%)$, bank rasio LDR nya diatas $110 \%$ berjumlah 16 bank, bank yang tidak efisien yang ditunjukan dengan nilai rasio BOPO lebih besar daripada $94 \%$ berjumlah 23 bank, dan bank yang profitabilitasnya (ROA) tidak sehat atau kurang dari 1,25\% berjumlah 32 .

\section{Tabel 1. Daftar Klasifikasi Status Bank}

\begin{tabular}{|c|c|c|c|c|}
\hline No & \multicolumn{2}{|c|}{ Status Bank } & $\mathrm{Jlh}$ & $\%$ \\
\hline 1 & \multicolumn{2}{|l|}{ Bank Persero } & 3 & 4.6 \\
\hline 2 & $\begin{array}{l}\text { Bank Umum } \\
\text { Nasional Devisa } \\
\text { Devisa) }\end{array}$ & $\begin{array}{l}\text { Swasta } \\
\text { (BUSN }\end{array}$ & 15 & 23.08 \\
\hline 3 & $\begin{array}{l}\text { Bank Unium } \\
\text { gitsional Non } \\
\text { (BUSN Non) }\end{array}$ & $\begin{array}{l}\text { Swasta } \\
\text { Devisa }\end{array}$ & 13 & 20 \\
\hline 4 & Bank BPD & & 19 & 29.23 \\
\hline 5 & Bank Campuran & & 7 & 10.77 \\
\hline 6 & Bank Asing & & 8 & 12.31 \\
\hline & \multicolumn{2}{|l|}{ Jumlah } & 65 & 100 \\
\hline
\end{tabular}

Sumber: Direktori Perbankan Indonesia 2014 (data olahan) 
Berdasarkan hasil pengamatan pada tahun penelitian, diperoleh suatu gambaran mengenai kinerja perbankan yang ditunjukan melalui resiko keuangan 65 bank yang dikategorikan sebagai bank sehat.

Tabel 2 menunjukkan hasil rangkuman mengenai kinerja keuangan perbankan yang dilihat dari empat rasio yang dijadikan variabel penelitian.

Tabel 2. Deskripsi Unit Observasi (dalam persentase)

\begin{tabular}{llllll}
\hline & N & Min & Max & Mean & Std. \\
\hline RO & 65 & 1.27 & 15.04 & 3.26 & 2.02 \\
A & 65 & 10.80 & 91 & 26.27 & 15.46 \\
CAR & 65 & 22.00 & 109.53 & 78.02 & 20.36 \\
LDR & 65 & 29.88 & 91.30 & 75.04 & 12.95 \\
BOPO & & & & & \\
\hline
\end{tabular}

Sumber: Outputt SPSS (Data Olahan)

Berdasarkan tabel rata-rata CAR 65 bank umum yang menjadi objek pengamatan adalah sebesar $26,27 \%$, dengan rata-rata bank persero sebesar $14,99 \%$, bank-bank swasta devisa tercatat $22,37 \%$ bank swasta non devisa sebesar 33,75\%, bank BPD 20,63\% bank campur $31,30 \%$ dan bank asing $34,6 \%$. rata-rata CAR ini menunjukan bahwa modalyang dimiliki mampu menutupi $26,27 \%$ resiko atas kegiatan usaha yang dilakukan bank. Posisi keuangan pada tahun penelitianmenunjukan nilai CAR tertinggu dimiliki oleh Bank of America, NA (Bank Asing) sebesar $91 \%$ sedangkan nilai CAR terendah dimiliki oleh Bank Permata, Tbk (BUSN Devisa) sebesar 10.8\%. Loan to Deposit Ratio (LDR) merupakan salah satu rasio yang digunakan untuk mengetahui tingkat likuiditas suatu bank. Selama tahun penelitian, bank yang memiliki tingkat LDR tertinggi adalah PT.OCBC Indonesia (Bank Campur) sebesar 109,53\% sedangkan tingkat LDR terendah dimiliki oleh Bank of China Limited (Bank Asing) 22\%.

Bank Indonesia menetapkan batas maksimal LDR yang dianggap sehat yaitu sebesar $110 \%$ apabila nilai LDR lebih dari $110 \%$ maka bank tersebut dapat dikategorikan sebagai bank tidak sehat (Siamat, 2004). Selain itu Bank Indonesia mensyaratkan bahwa bank yang dinyatakan sehat adalah bank yang dimiliki rasio BOPO kurang dari 94\% (SE No.6/23/DPNP/2004).

\section{Pembahasan}

Bank merupakan organisasi yang melakukan kegiatan usaha memberikan jasa dalam lalu lintas pembayaran kepada masyarakat. Bank adalah penyalur modal dari yang tidak dapat menggunakannya secara menguntungkan kepada pihak-pihak yang bisa menjadikannya lebih produktif bagi keuntungan masyarakat (Kasmir, 2007). Bank, khususnya bank umum, juga merupakan lembaga keuangan pencipta uang giral, pengumpul dana dan penyalur kredit, pelaksana lalu lintas pembayaran, stabilisator moneter, serta dinamisator pertumbuhan perekonomian (Hasibuan, 2006). Fungsi stabilisator meter menunjukkan bank memiliki kewajiban untuk ikut serta dalam menjaga stabilitas nilai tukar uang nasional, nilai kurs, ataupun harga-harga barang agar relatif tetap atau stabil. Peran dinamisator perekonomian menunjukkan bank merupakan pusat perekonomian, sumber dana, dan pelaksana transaksi.

Pada penelitian, proses analisis dimulai dengan melakukan uji asumsi klasik atas data. Tahap selanjutnya akan dilakukan proses analisis regresi linier berganda, analisis determinasi, dan uji hipotesis.

Sebelum dilakukan uji normalitis, data yang akan diuji harus terbatas dari data yang outlier. Hasil analisis mendeteksi ada enam sampel yang nilai rasionya bersifat outlier sehingga data tersebut tidak dapat digunakan kembali dalam pengujian selanjutnya.

Untuk mengetahui yang dijadikan objek penelitian telah berdistribusi normal penelitian ini menggunakan Uji KolmogorovSmirnov (K\&S). Apabila nilai signifikansi tiap variabel lebih besar atau sama dengan taraf signifikan 5\%, maka dapat dinyatakan bahwa data telah berdistribusi normal.

Tabel 3 memperlihatkan bahwa seluruh data variabel penelitian memiliki nilai K\&S lebih besar dari taraf signifikan yang 
digunakan sehingga dapat ditarik kesimpulan bahwa seluruh data telah berditribusi normal.

Tabel 3. Hasil Pengujian Normalitas (Uji K \& S)

\begin{tabular}{llll}
\hline $\begin{array}{l}\text { Variabel } \\
\text { Penelitian }\end{array}$ & $\begin{array}{l}\text { Nilai } \\
\text { K\&S }\end{array}$ & $\begin{array}{l}\text { Asymp. } \\
\text { Sig. (2- } \\
\text { tailed) }\end{array}$ & Kesimpulan \\
\hline ROA & 0.707 & 0.699 & $\begin{array}{l}\text { berdistribusi } \\
\text { normal } \\
\text { berdistribusi } \\
\text { normal } \\
\text { berdistribusi } \\
\text { normal } \\
\text { berdistribusi } \\
\text { normal }\end{array}$ \\
\hline
\end{tabular}

Sumber: Output SPSS (Data Olahan)

\section{Hasil Pengujian Asumsi Klasik}

Sebelum digunakan analisis regresi berganda untuk mengetahui bagaimana perubahan variabel terikat apabila terjadi perubahan pada variabel bebas, perlu untuk dilakukan pengujian pelanggaran asumsi klasik. Hal ini dimaksudkan agar model regresi yang dihasilkan tidak bisa hingga telah memenuhi BLUE (Best Linier Unbiased Estimator)

\section{Uji Multikolinieritas}

Penilitian ini menggunakan nilai Tolerance dan nilai Variant Inflation Factor (VIF) untuk mengindetifikasikan adanya multikolinieritas. Apabuila nilai tolerance lebih besar dari pada 0,1 dan nilai VIF lebih kecil dari pada 10 artinya tidak terjadi multikolinieritas. Tabel 4 menunjukkan hasil uji multikolinieritas menggunakan program olah data SPSS.

\section{Tabel 4. Hasil Pengujian Multikoliniers}

\begin{tabular}{|c|c|c|c|}
\hline Var & Tolerance & VIF & Keputusan \\
\hline CAR & 0.972 & 1.029 & $\begin{array}{l}\text { Tidak } \\
\text { multikolinieritas }\end{array}$ \\
\hline LDR & 0.941 & 1.063 & $\begin{array}{l}\text { Tidak } \\
\text { multikolinieritas }\end{array}$ \\
\hline BOPO & 0.929 & 1.077 & $\begin{array}{l}\text { Tidak } \\
\text { multikolinieritas }\end{array}$ \\
\hline
\end{tabular}

Sumber: Output SPSS (Data Olahan)

\section{Uji Autokolerasi}

Untuk mendeteksi adanya probabilitas terjadinya kondisi autokolerasi, penelitian ini menggunakan uji Durbin-Watson (DW). Berdasarkan pengolahan data denagn SPSS diketahui nilai Durbin-Watson (DW) adalah sebesar 1,610. Dikarenakan sampel yang digunakan sebanyak 59 bank dari variabel bebas yang diujikan sebanyak 3 variabel, maka nilai $d_{u}=1,678$ dan nilai $d_{u}=1,474$.

Tabel 5 menunjukan nilai DW sebesar 1,610 masuk kedalam kriteria kelima yaitu $1,474<\mathrm{DW}<1,678$ dimana kriteria ini merupakan grey area yang hasil keputusan tidaknya autokolerasi tergantung kepada keputusan penelitian. Oleh karena itu penelitian dapat menarik kesimpulan bahwa model regresi yang digunakan untuk terjadinya autokolerasi atau antara pengamatan yang satu dengan pengamatan yang lain tidak terjadi kolerasi residual.

\section{Tabel 5. Kriteria Uji Autokoleransi}

\begin{tabular}{|c|c|c|}
\hline No & Nilai DW & Kesimpulan \\
\hline 1 & $2,525<\mathrm{DW}<4$ & $\begin{array}{l}\text { Terjadinya } \\
\text { autokolerasi }\end{array}$ \\
\hline 2 & $0<\mathrm{DW}<1,474$ & $\begin{array}{l}\text { Terjadinya } \\
\text { autokolerasi }\end{array}$ \\
\hline 3 & $2<\mathrm{DW}<2,312$ & $\begin{array}{l}\text { Terjadinya } \\
\text { autokolerasi }\end{array}$ \\
\hline 4 & $1,687<\mathrm{DW}<2$ & $\begin{array}{l}\text { Terjadinya } \\
\text { autokolerasi }\end{array}$ \\
\hline 5 & $\begin{array}{l}1,474<\mathrm{DW}< \\
1,687 \text { atau } 2,312< \\
\mathrm{DW}<2,525\end{array}$ & $\begin{array}{l}\text { Tidak ada } \\
\text { kesimpulan } \\
\text { (Grey Area) }\end{array}$ \\
\hline
\end{tabular}

Sumber: Data Olahan

\section{Uji Heterokedastisitas}

Penguji ada tidaknya heterokedastisitas dengan menggunakan uji glejser dilakukan dengan meregresikan variabel terikat (Y) yang sebelumnya telah diubah kedalam bentuk absolute residual dengan seluruh variabel bebas dalam penelitian ini. Berikut ini hasil uji glejser (Glejser Test) dengan menggunakan SPSS.

Berdasarkan nilai Sig. pada Tabel 6 dapat diinterprestasikan bahwa nilai Sig. semua variabel independen $(0,512,0,240$, dan 0,232$)$ 
Tabel 6. Hasil Uji Heterokedastisitas

\begin{tabular}{llll}
\hline $\begin{array}{c}\text { Variabel } \\
\text { Bebas }\end{array}$ & t.hitung & \multicolumn{1}{c}{ Sig. } & \multicolumn{1}{c}{ Kesimpulan } \\
\hline CAR & -661 & 0.512 & Homokedastisitas \\
LDR & 1.188 & 0.240 & Homokedastisitas \\
BOPO & -210 & 0.233 & Homokedastisitas \\
\hline
\end{tabular}

Sumber: Output SPSS (Data Olahan)

lebih besar dari pada 0.05 sehingga dapat di tarik suatu kesimpulan bahwa seluruh variabel bebas tidak mengandung heterokedastisitas atau varian residual dari suatu observasi ke observasi lainnya sama.

\section{Hasil Analisis Regresi Linier Berganda}

Pengujian regresi berganda berfungsi untuk mengetahui bagaimana pengaruh penurunan ataupun peningkatan variabel bebas terhadap nilai variabel terikat. Berdasarkan perumusan masalah dan hipotesis yang telah di tetapkan, Tabel 7 merangkum hasil pengolahan data regresi dengan menggunakan SPSS.

Dari nilai koefisien regresi pada table didapatkan model persamaan regresi berganda untuk memperkirakan perubahan variabel terikat (Y) atas perubahan variabel bebas (X) sebagai berikut:

$\mathrm{Y}=11,003-0,006 \mathrm{CAR}+0,013 \mathrm{LDR}-0,116 \mathrm{~B} 0 \mathrm{P} 0$

Dari model persamaan regresi berganda diatas dapat diinterprestasikan bahwa; (a) ketika tidak ada nilai (nol) pada CAR, LDR, dan BOPO, nilai ROA bernilai konstan sebesar 11,003.

\section{Hasil Uji ANOVA (F test)}

Dari hasil Uji Anova atau F Test diperoleh nilai $F_{\text {hitung }}$ sebesar 45,16 dengan probabilitas 0,000. nilai daripada $F$ tabel $(3,1619)$ sehingga diketahui bahwa model regresi ditentukan dapat digunakan untuk memprediksi kinerja profitabilitas (ROA) atau dapat dikatakan bahwa CAR, LDR, dan BOPO secara bersama-sama berpengaruh terhadap ROA.

\section{Hasil Pengujian Hipotesis \\ Pengujian hipotesis dalam penelitian}

ini dilakukan secara parsial dengan menggunakan uji untuk mengetahui bagaimana pengaruh nyata antara variabel bebas dengan variabel terikat secara individu. Apabila nilai $\mathrm{t}_{\text {hitung }}>\mathrm{t}_{\text {table }}$ dan nilai signifikan $<$ tingkat kesalahan (5\%) yang digunakan, maka dapat ditarik suatu kesimpulan bahwa terdapat pengaruh yang nyata antara variabel bebas dengan variabel terikat.

Berdasarkan Tabel 7, nilai $\mathrm{t}_{\text {hitung }}$ CAR $\left(\mathrm{X}_{1}\right)$ sebesar $-0,752<$ tabel $(2,004)$ dan nilai Sig. 0,455 > 5\% sehingga dapat disimpulkan bahwa secara hipotesis $\mathrm{H}_{1}$ di menerima dan tolak $\mathrm{H}_{2}$. Hal ini menunjukan bahwa tidak terdapat pengaruh signifikan antara CAR dengan ROA.

Berdasarkan Tabel 7, menunjukan nilai $t_{\text {hitung }} \operatorname{LDR}\left(\mathrm{X}_{2}\right)$ Sebesar 2,690>t tabel $(2,004)$ dan nilai Sig. sebesar $0.009<5 \%$ sehingga keputusan yang dapat diambil adalah menolak $\mathrm{H}_{1}$ dan menerima $\mathrm{H}_{2}$. Dengan kata lain, terdapat berpengaruh yang signifikan antara LDR dengan ROA, sedangkan tanda positif pada $t_{\text {hitung }}$ menunjukan hubungan yang positif antara LDR dan ROA.

Berdasarkan tabel 7 , nilai terhitung BOPO (X3) sebesar $-11,594>t_{\text {abel }}(2,004)$ dan nilai Sig. $0,000<5 \%$ sehingga keputusan yang diambil adalah menolak $\mathrm{H}_{0}$ dan menerima $\mathrm{H}_{2}$ yang artinya terdapat pengaruh signifikan antara BOPO dengan ROA. Selain itu tanda negatifpada $t_{\text {hitung }}$ menunjukkan hubungan yang negatif antara BOPO dengan ROA.

Tabel 7 juga menunjukan nilai koefisien determinasi (adjusted $R$ square) sebesar 0,696 atau $69.6 \%$ yang artinya variabel bebas dalam penelitian ini secara bersama-sama mampu mempengaruhi perubahan ROA sebesar 69,6\%. Sedangkan sisanya dipengaruhi oleh variabel lain yang tidak diteliti dengan baik dan kuat. Dengan kata lain dalam penelitian ini menunjukan bahwa variabel bebas yang dipilih yaitu CAR, LDR, dan BOPO dapat menjelaskan dengan baik terhadap variabel tidak bebas yaitu RA. Selain itu, dari nilai koefisien determinasi juga menunjukan pengaruh yang kuat dari ketiga variabel bebas. Berikut ini penjelasan mengenai pengaruh ketiga variabel bebas tersebut: 
Tabel 7. Hasil Analisis Statistik

\begin{tabular}{lccc}
\hline Variabel & $\mathrm{B}$ & $\mathrm{t}$ & Sig. $\mathrm{t}$ \\
\hline Konstanta & 11,003 & 12,328 & 0,000 \\
CAR & $-0,006$ & 752 & 0,455 \\
LDR & 0,013 & 2,690 & 0,009 \\
POPO & -116 & 11,594 & 0,000 \\
\hline Adjusted R. Square & $=0,696$ & & \\
F & $=45,16$ & & \\
Sig. F & $=0,000$ & & \\
\hline
\end{tabular}

Sumber: Data Primer diolah, 2017

\section{Pengaruh CAR terhadap ROA}

Berdasarkan hasil pengujian hipotesis secara parsial, nilai nilai $t_{\text {hitung }} \mathrm{CAR}$ (Xi) sebesar $-0.752<\mathrm{t}_{\text {tabel }}(2,004)$ dan koefisien regresi pada persamaan regresi $(-0,0006)$ menunjukan bahwa tidak terdapat pengaruh signifikan antara CAR dengan ROA yang adanya peningkatan atau penurunan nilai rasio CAR tidak memiliki pengaruh signifikan terhadap ROA. Namun berdasarkan nilai koefisien regresi diperkirakan peningkatkan rasio CAR akan menurunkan kinerja profitabilitas bank besar $0,006 \%$ atau hubungan negatif antara CAR dengan ROA.

\section{Pengaruh LDR terhadap ROA}

Hasil pengujian hipotesis dengan menggunakan uji $t$ menghasilkan nilai terhitung LDR $\left(\mathrm{X}_{2}\right)$ sebesar $2.690>\mathrm{t}_{\text {tabel }}$ $(2,004)$ yang menunjukan terdapat pengaruh signifikan yang positif antara LDR dengan tingkatan profitabilitas (ROA) dan dari nilai konfisien regresi diperkirakan ketika terjadi peningkatan terhadap $1 \%$ LDR akan meningkatkan kerja profitabilitas sebesar $0,013 \%$.

Hasil penelitian ini berbeda dengan hasil penilitian yang dilakukan oleh Siagian dan Yasin. (2009) serta penelitian yang dilakukan oleh Yuliani (2007) yang menyatakan terdapat pengaruh antara LDR dan profitabilitas ROA sedangkan secara ratarata tahunan LDR hanya 60,54\% (2004), 63,77\% (2005) dan 64,60\%(2006).

Kesimpulan yang dapat diambil atas perbedaan hasil penelitian ini adalah dengan memaksimalkan penyaluran kredit tanpa melebihi batas aman likuiditas untuk tetap menjaga kepercayaan masyarakat dapat berpengaruh signifikan terhapat kinerja profitabilitas yang di produksi dengan ROA.

\section{Pengaruh BOPO terhadap ROA}

Pada Uji-t yang telah dilakukan diperoleh nilai hitung BOPO $\left(\mathrm{X}_{3}\right)$ sebesar $11,594>t_{\text {tabel }}(2,004)$ menunjukan pengaruh signifikan dan hubungan yang negatif antara rasio BOPO terhadap profitabilitas bank (ROA) yang artinya semakin tinggi rasio BOPO suatu bank akan semakin redah tingkat profitabilias yang akan dicapai. Berdasarkan koefisien regresi menunjukan peningkatan rasio BOPO sebesar $1 \%$ diperkirakan profitabilitas bank akan menurun $0,116 \%$

Biaya merupakan pengeluaran yang dilakukan oleh bank untuk menghasilkan pendapatan bagi bank. Semakin rendahnya rasio BOPO dapat menunjukkan kemampuan bank menutupi biaya bunga dan biaya operasional lainnya. Untuk itu, hasil penelitian ini sesuai dengan teori yang telah diungkapkan dalam kajian teori yang digunakan maka keuntungan yang dihasilkan akan semakin besar.

Hasil penelitian ini mendukung penelitian terlebih dahulu oleh Kesowo (dalam Mudrajad dan Kuncoro 2002), Sebatiningrum (2006) dan Yuliani (2007). Peningkatan ataupun penurunan kinerja profitabilitas tidak hanya dipengaruhi oleh faktor internal bank seperti yang diwakili dalam variabel yang diteliti tetapi kemungkinan juga dapat dipengaruhi oleh faktor lainnya seperti kondisi perekonomian, tingkat inflasi, maupun alternatif investasi.

\section{KESIMPULAN}

Kinerja profitabilitas perbankan 
menjadi suatu hal yang menjadi perhatian banyak pihak karena melalui pencapaian kinerja yang maksimal, bank dapat melakukan peningkatan atas kontribusinya dalam upaya mendorong pertumbuhan ekonomi. Kinerja profitabilitas merupakan gambaran prestasi yang diraih bank dalam melakukan aktivitas operasionalnya, yang pada dasarnya serupa dengan kegiatan ekonomi umunya yaitu untuk memperoleh keuntungan. Pendapatan operasional perbankan meliputi pendapatan bunga serta pendapatan operasional lainnya; sementara biaya operasional mencakup biaya bunga dan biaya operasional lainnya. Mempertimbangkan bahwa kegiatan utama dari bank adalah perantara atau penghimpun maupun penyalur dana, maka pendapatan maupun biaya operasional yang dimilikinya mayoritas merupakan hasil bunga dan biaya bunga

Bank Indonesia sebagai pihak beroritas untuk melakukan pengawasan terhadap bank-bank yang ada di Indonesia membuat suatu peraturan mengenai penilaian tingkat kesehatan bank. Dilihat dari beberapa rasio keuangan bank diketahui bahwa dari total bank umum yang menjadi populasi, 65 bank telah memiliki rasio keuangan yang tergolong sehat dan berdasarkan hasil pengujian hipotesa secara persial (uji-t) dan analisis regresi berganda terhadap 65 bank yang miliki rasio dapat dikategorikan sehat diketahui beberapa hal.

Pertama, terhitung lebih kecil dari pada $t_{\text {tabel }}$ dan nilai signifikannya yang menggunakn $(0,05)$ yang artinya Rasio kecukupan modal (Capital Adequacy Ratio$C A R$ ) tidak berpengaruh terhadap Return on Assets (ROA).

Kedua, Loan to Deposit Ratio (LDR) memiliki pengaruh yang ditunjukan dengan signifikan yang lebih kecil daripada tingkat signifikan yang digunakan.

Ketiga, hasil pengolahan dan analisis data menunjukan biaya operasional pendapan operasional (BOPO) berpengaruh signifikan dan pengaruhnya negatif terhadap kinerja profitabilitas bank artinya semakin rendah rasio BOPO akan kemungkinan akan semakin tinggi ROA bank.
Terakhir, ketiga rasio yang digunakan dalam penelitian ini memiliki pengaruh yang sangat kuat kinerja profitabilitas yang diukur dengan ROA yang ditunjukan dengan nilai koefisien determinasi yang tinggi melebihi 0,5 .

\section{DAFTAR PUSTAKA}

Anam, Muhammad Khairul. 2009. Pengaruh Asset Liability Management terhadap Kinerja Bank Tahun 2006-2008. Skripsi. UIN Sunan Kalijaga. Yogyakarta

Ahnilia, Luciana dan Winny Herdiningtyas. 2005. Analisis Rasio CAMEL terhadap Prediksi Kondisi Bermasalah pada Lembaga Perbankan perioda 20002002. Jurnal Akuntansi dan Keuangan. Vol. 7. No. 2. Hal: 1-27.

Bank Indonesia. Laporan Pengawasan Perbankan 2008. Diperoleh dari www.bi.go.id.

Bank Indonesia 2009. Direktorat Perbankan Indonesia 2008. Jakarta

Ghozali, Imam. 2006. Aplikasi Analisis Multivariate dengan Program SPSS. Semarang: FE UNDIP.

Hasibuan, Malayu S.P. 2006. Dasar-Dasar Perbankan. Jakarta: PT. Bumi Aksara.

Judiseno, Rimsky K. 2002. Sistem Moneter dan Perbankan di Indonesia. Jakarta: Gramedia Pustaka Umum.

Kasmir. 2007. Manajemen Perbankan. Jakarta: PT. Raja Grafindo Persada.

Kuncoro, Mudrajad dan Suhardjono. 2002. Manajemen Perbankan Teori dan Aplikasi. Yogyakarta: BPFE UGM.

Leunupun, Pieter. 2003. Profitabilitas Ekuitas dan Beberapa Faktor yang Mempengaruhinya: Studi pada Beberapa KUD di Kota Ambon. Jurnal I dan Keuangan. Vol. 5. No. 2. Hal: 23-32.

Lo, Eko Widodo. 2001. Rasio Keuangan untuk Mengukur Asosiasi Likuiditas, Struktur Modal, dan Kualitas Aktiva dengan Profitabilitas Bank: Analisis Korelasi Kanonikal. Jurnal Bisnis dan Akuntansi. Vol. 3. No. 1. Hal: 315334. 
Martono, Cyrilius 2002. Analisis Pengaruh Profitabilitas Industri, Rasio Leverage Keuangan Tertimbangdan Intensitas Modal Tertimbang serta Pangsa Pasar terhadap "ROA" dan "ROE" Perusahaan Manufaktur yang Go Publik di Indonesia. Jurnal Akuntansi dan Keuangan. Vol. 4. No. 2. Hal: 126-140. Mawardi, Wisnu. 2004. Analisis Faktor Faktor Yang Mempengaruhi Kinerja Keuangan Bank Umum di Indonesia (Studi Kasus Pada Bank Umum Dengan Total Asset Kurang Dari 1 Trilyun). Skripsi. Universitas Diponegoro.

Merkusiwati, Ketut Leli Aryani. 2007. Evaluasi Pengaruh CAMEL terhadap Kinerja Perusahaan. Bulletin Studi Ekonomi. Vol, 12, No, 1. Hal: 100-108. Panggabean, Priska. 2007. Pengaruh Value At

Risk Valuta Asing pada Profitabilitas Bank Umum Swasta Nasional Devisa di Indonesia. Tesis. Pascasarjana UGM.

Prasetyo dan Lina Miftahul. 2008. Metode

Penelitian Kuantitatif: Teori dan Aplikasi. Jakarta: PT. Raja Grafindo Persada.

Priyanto, Duwi. 2009. SPSS Untuk Analisis Kolerasi, Regresi, dan Multivariate. Yogyakarta: Gava Media

Rivai, Veithzal, dkk. 2007. Bank And Financial Institution Management. Edisi Kesatu. Jakarta: PT. Raja Grafindo Persada

Sebatiningrum, Nur Khasanah. 2006. Pengaruh Capital Adequacy Ratio
(CAR), Likuiditas dan Efisiensi Operasional Profitabilitas Perusahaan Perbankan yang Terdaftar di Bursa Efek Jakarta. Skripsi. Universitas Negri Semarang.

Siamat, Dahlan 2004. Manajemen Lembaga

Keuangan. Jakarta: Fakultas Ekonomi Universitas Indonesia.

Standar Akuntansi Keuangan. 2009. Akuntansi Perbankan No 31. Jakarta: Salemba Empat.

Sugiyono. 2007. Statistika Untuk Penelitian. Bandung: CV Alfabeta.

Suharyadi dan Purwanto S.K. 2004. Statistika Untuk Ekonomi dan Keuangan Modern. Jakarta: Salemba Empat.

Syaidah, Nur. 2007. Pengaruh Kualitas Corporate Governance terhadap Kinerja Perusahaan Public (Studi Kasus peringkat 10 besar CGPI). Jurnal Oksciansi dan Audizing Indonesia. Vol. 11. No. 1. Hal: 1-19.

William, Dermawan. 2006. Manajemen Kinerja: Konsep, Design, dan Teknik Meningkatkan Daya Saing Perusahaan. Jakarta: Erlangga.

Yuliani. 2007. Hubungan Efisien Operasional dengan Kinerja Profitabilitas pada Sektor Perbankan yang Go Public di Bursa Efek. Jakarta. Jurnal Manajemen \& Bisnis Sriwijaya. Vol. 65. No. 10. Hal: 16. 